Stephen R. Christ

Truman State University, U.S.A.

https://doi.org/10.18778/1733-8077.12.2.03

\title{
Matachines in the Midwest: Religion and Identity
} in the American Heartland

Abstract This article examines how a community of recent Mexican migrants and their families use popula religious practices to sustain a sense of ethnic Mexican identity in a predominantly White rural Catholic Church where their growing presence and influence are changing how Catholicism is practiced. In this rural setting, participation in a Matachines dance tradition functions to bring the Mexican community together, place before them a common tradition uniquely their own, and build up distinctive emotions in them around ritual traditions which in turn serve as a pillar of strength for maintaining their ethnic identity through the perpetuation of religious practices and symbols. More specifically, two dimensions are of central focus in this article: tensions arising from ethnic expressions through the institutional Church and the contested meanings of specific rituals and religious symbols such as Matachines and La Virgen de Guadalupe. Based on two years of ethnographic fieldwork, this research presents evidence of a modern transformation of U.S. religious practices as a result of immigration from Mexico into the Midwestern United States.

Keywords Identity; Religion; Immigration; Ethnicity; Matachines

Stephen R. Christ is an Assistant Professor of Sociology at Truman State University. In his research, Stephen examines the everyday experiences of Mexican immigrants in the United States that contribute to Mexican-American identity formation. More specifically, how Mexican-Americans experience daily life at home, at work, in public life and in how these experiences impact their sense of personal identity, their relationships with natives, their interactions with their families and community, and the identity work that goes into producing such categories and social worlds.

email address: schris@@ruman.edu most immigrant-native interactions leave out a significant portion of the U.S. Latino/as population, those living in the many new destinations in the Midwestern United States.

The influence of the Mexican immigrant population is beginning to reshape the social, political, and demographic landscape of the United States outside of the Southwestern Borderlands (Kandel and Cromartie 2004; Zuniga and Hernandez-Leon 2005; Saenz, Cready, and Morales 2007). However, over the last twenty years, little has been written about the experiences, group identities, assimilation, and social integration of immigrant Latino/as, particularly in the Midwest (Waters and Jimenez 2005). Most ethnographic research on Mexicans in the United States has focused on the communities of the Southwestern Borderlands (Macias 2004; Massey and Sanchez 2006; Gomez 2007). There is no question that studies of the Borderlands are relevant to Mexican-American immigrant settlement, but there is clear evidence that migration patterns and immigrant experiences have drastically changed over the past two decades, which requires scholarly focus in order to properly understand contemporary Mexican immigration to the United States (Durand, Massey, and Charvet 2000; Kandel and Cromartie 2004)

For example, in 1910, 95\% of Mexican-Americans lived in the Southwest; in 1990, that percentage had reduced to $83 \%$, and in 2000 , it decreased to $75 \%$ (Guzman 2001; Saenz, Cready, and Morales 2007), leaving $25 \%$ of Mexicans spread throughout other regions of the United States. The most recent estimates of Mexican-Americans place the population at roughly thirty million individuals (Tafoya 2004-
2005). According to these figures, this accounts for roughly seven and a half million Mexican-Americans living in areas which previously had little to no Mexican immigration such as the Midwest. The availability of jobs in construction, agriculture, and animal processing plants is commonly attributed with the increase of outward migration from the Southwest and the development of communities in rural areas (Kandel and Gibbs 2005).

Continuing with the trend of new immigrant gateways, $21 \%$ of Mexican immigrants have begun to settle in rural settings (Arreola 2004; Lichter et al. 2007). Such migration of Mexican immigrants to rural areas in the Midwest has not occurred without opposition. Similar to the plight of African-Americans during the Great Migration, Mexicans and Mexican-Americans across the Midwestern states have been subjected to segregation, isolation, and physical violence (Fuhlhage 2007; Lichter et al. 2007). In rural areas where some immigrant Mexican communities are settling, this same opposition is occurring to this day. Faced with this reality, immigrant populations oftentimes create tightknit, closely connected communities by which they structure their lives and attempt to maintain a sense of normalcy.

One of the major institutional foundations which remains consistent in Mexican immigrant transition to the U.S. is the Roman Catholic Church. Noting this phenomenon in her own research, Maria Arbelaez (2002) writes,

Deeply embedded in Mexicans is their affiliation to popular religiosity, in particular their devotion to the 
Virgin of Guadalupe, religious drama, and to the memorial of the Day of the Dead. These celebrations have crossed the border without the formality of a visa, ventured ever further north, and have surfaced in the Heartland of America. [p. 14]

Mexican-Americans maintain their ethnic identity through religious practice despite being thousands of miles away from their homeland. In this sense, religion plays multiple roles in the lives of immigrants struggling to maintain an ethnic identity. In particular, this article will theoretically analyze the political, social, and religious integration of a small group of rural Mexican immigrants into a rural and predominantly White Catholic Church in the Midwestern United States. Special emphasis is placed on the responses of White natives to changes in local organizational religious practices, including language of prayer, days of celebration, and involvement in the church leadership hierarchy. Furthermore, two dimensions are of central interest: tensions arising from ethnic expressions through the institutional Church and the contested meanings of specific rituals and religious symbols such as Matachines and La Virgen de Guadalupe in the lives of immigrants and Natives.

\section{Catholicism as an Ethnic Marker}

Previous studies of new immigrant communities (Menjívar 1999; Yang and Ebaugh 2001) have found that religion serves as a major source of immigrant ethnic identity preservation. When describing the link between religion and ethnicity, some scholars (Stout 1975) go so far as to describe the association as "ethnoreligion." Immigrant proclivity to join re- ligious communities can be attributed to a range of motivations. Desire for religious and spiritual support, the ability to spend time with other ethnics, and the development of social networks all serve as pull factors by local congregations (Yang and Ebaugh 2001; Cadge and Ecklund 2006). Some ethnic groups (Amish, Jews, etc.) emphasize religion as the core determinant of identity (Gordis and Ben-Horin 1991). Others use religion, as Yang and Ebaugh (2001) suggest, as a means of preserving cultural traditions and ethnic boundaries. This is to say that religious fervor in immigrant communities serves two purposes: the first being an actual devotion to the religious symbols and rituals, and secondly, to create a cultural support system for immigrants by filtering external influences of mainstream American culture in order to preserve communal solidarity in an ethnic immigrant community.

Phillip Hammond and Kee Warner's (1993) development of "religious ethnicity" may best describe the intertwining of Mexican ethnicity and religious faith. Mexican immigrants often situate themselves under the umbrella of the Catholic Church. Religion and spirituality have enabled Mexican-Americans to create a distinct marker of ethnic identity. However, as Irene Blea (1988) points out, the teachings of the Roman Catholic Church alone cannot be attributed to the development of this group identity. In order to understand religious devotion among Mexican immigrants, elements of indigenous religions and other cultural influences must be included. It is here where Matachines traditions and public devotion to La Virgen de Guadalupe distinguishes Mexican immigrants from all other groups, including American Catholics. It is the practice of this "ethnoreligion" which maintains a unified immigrant community and allows for the perpetuation of ethnicity by the synthesis of religious practices and doctrine and religious needs.

\section{La Virgen de Guadalupe and Matachines Traditions}

Matachines are religious dancers who perform in predominantly Mexican and Mexican-American Roman Catholic ceremonies on the December $12^{\text {th }}$ feast day of La Virgen de Guadalupe. Through traditional dance, the drama of Montezuma, an Aztec king, and La Malinche, an infamous historical figure in Mexico heralded by some as a heroine and others as a traitor to her people, is presented. The dance group is a very organized unit with each member playing an important role in the overall presentation of the dance. The dance is an account of good (Montezuma and La Malinche) versus bad (Hernán Cortés) with the good side prevailing.

The dances are always performed with an image of La Virgen de Guadalupe present. One aspect of the dance that remains unknown is its exact origin. Similarly, the history of La Virgen de Guadalupe is another hotly debated topic. According to some historians, La Virgen de Guadalupe was represented as a Christianized Tonantzin, a major goddess of the Aztecs, to convert the indigenous populations to Catholicism. Emphasizing this argument, Jacques Lafaye (1976:214) wrote in Quetzalcoatl and Guadalupe, "as the Christians built their first churches with the rubble and the columns of the ancient pagan temples, so they often borrowed pagan customs for their own cult purposes." According to Catholic tradition,
Juan Diego, an indigenous laborer and Christian convert, was on his way to church to celebrate the Holy Mass on December $9^{\text {th }}$, 1531. On his way, he passed Tepeyac hill, a region associated with the Aztec goddess, Tonantzin. It was there that he heard wonderful music and saw the most beautiful women he had ever seen. She had dark skin, as did Juan and other indigenous peoples of the region, and was radiating light all around her as she introduced herself to him as the Blessed Virgin Mary. The color of her skin was an important symbol in itself. White skin was associated with the Spaniards and carried with it a connotation of a superior class. By having brown skin, La Virgen de Guadalupe was associating herself with the indigenous peoples and showing that they were just as important in God's eyes. Due to this, the Matachines dance is both symbolically and institutionally now rooted in the Roman Catholic Church even though its roots were clearly linked to indigenous, pagan sources, as well as rooted in European dance traditions. It now reflects fundamental aspects of Mexican culture and identity.

In general, most scholars agree that the Matachines derives from a genre of medieval European folk dramas symbolizing conflict between Christians and Moors, brought to the New World by the Spaniards as a vehicle for Christianizing the Indians (Kurath 1949; Delgado 2007; Rodriguez 2007). Iberian elements merged with aboriginal forms in central Mexico, and the syncretic complex was transmitted to Indians farther north, including the Rio Grande Pueblos, probably via Mexican Indians who accompanied the Spanish colonizers (Rodriguez 2007). As the elements began to merge, the tradition of Matachines dancing as it is understood 
today began to form. Over time the traditions underwent gradual changes. Ethnic studies scholars (Kelly and Karner 1994) argue that ethnic groups at times invent traditions like this to reinforce their group identity. The Matachines dance group in this study would serve as a representative example of this "invented tradition." The dancers, in a way, are history teachers providing what they believe to be the history of their people. Although no empirical or historical data support their claims of the origin of the tradition, the Matachines traditions in this rural community serve an integral function. They bring the Mexican community together, place before them a common tradition uniquely their own, and build up distinctive emotions in them around those ritual traditions which in turn serve as a pillar of strength for maintaining their ethnic identity through the perpetuation of religious practices and symbols.

\section{Data and Methods}

To investigate the social, political, and religious integration of a small group of Mexican immigrants in the rural Midwest, an ethnographic study consisting of 30 interviews and two years of participant observation at a rural Midwestern Catholic Church was conducted. Given the focus on new immigrant integration and Matachines traditions, I consciously sought out potential respondents who met the following criteria. First, all were first generation immigrants from Mexico. Second, all respondents were practicing Catholics in the parish sponsoring the Matachines traditions. This lead to slight complications in the data collection process as some participants and observers of the Matachines celebrations were not Catholics but fol- lowers of various other protestant denominations. While not pursuing participation in the Matachines traditions for religious reasons, these participants often cited a desire for a familiar cultural experience and opportunity to interact with fellow immigrants as their main determinant for joining the dance group, highlighting the dual function of the dance group as a means of achieving religious/ spiritual fulfillment and social networking possibilities. Finally, all respondents were active members of the church Matachines dance group who had performed at the annual feast day celebration of La Virgen de Guadalupe in the past year.

Participant observation was a vital tool for producing an accurate representation of the integration of the new immigrant community. Over the two year time span of this study, I immersed myself in the local community and befriended several of the respondents. I believe it was my acceptance into this tight-knit and more or less closed community that greatly impacted the data I was able to be exposed to and gather. Through my attendance at weekly Matachines dance practices and semi-monthly performances at both religious ceremonies, and in one case, a second grade child of a dancer's special show-and-tell day at school, as well as various church celebrations, bible study sessions, and various other Hispanic Ministry group meetings, I was able to observe firsthand the integration experiences of Mexican immigrants. In general, the audience for such performances was predominantly composed of Mexican immigrants and their families. A trend of tensions between religious ritual synchronization involving mainstream Midwestern Catholic traditions and Mexican migrant Catholic traditions often led to segregated audiences and limited performance venue opportunities in the Church.

\section{Sample}

The Matachines dance group is composed of roughly forty adult full-time members. Many children of dancers are themselves participants, but participate on a less frequent basis, often preferring to play sports with friends across the church gymnasium from dance practice. All members who participated in this study were practicing Catholics. None of the men interviewed possessed a college degree. Almost all were manual laborers in one form or another, working as gardeners, construction workers, and butchers. The women interviewed were no different from the men when it comes to education as again none possessed a college degree. The women worked primarily as homemakers, with only a small minority in the labor force working in the service industry as maids, waitresses, and seamstresses. I found that all respondents lived working class lives and possessed little economic capital, but instead relied heavily on their social capital within the small immigrant community for support. However, respondents never complained about lack of money or hardships associated with jobs or finances. These dancers were proud of their Mexican heritage and identity and were confident of their religious values as being the most important factor in their lives. Spanish was the preferred language of most respondents as almost half were unable to speak English.

The rural Matachines dance group is located in the Midwest. The site was selected for this study be- cause of the rural nature of the new immigrant destination. As I learned through my interviews, the community is relatively new with most Mexican immigration to the area occurring within the last ten years. Situated one hour away from a major city and Mexican population, the respondents in this study answer are relatively isolated from contact with Mexican immigrants outside of their small community. In their local church, St. Stephen's, the Mexican immigrants constitute a tiny fraction of the congregation of roughly 800 parishioners, of which approximately $95 \%$ are White.

The testimonies provided by respondents in this study are not academic discourse; rather, they are personal accounts and perceptions of the individuals at hand. The data produced by this study lend themselves to diverse interpretations as to the significance of immigrant Mexican status in the Midwestern United States, the role of Catholic Church in assimilation of immigrants, and the agency of immigrants in shaping their "American" experience. However, this study is not intended to represent any particular immigrant population, nationality, or religious community. The purpose of this study was not to create a holistic generalization of the Midwestern Mexican immigrant experience. Instead, the data highlight one particular context of Mexican immigrant integration in the rural Midwest and reflect issues relevant to the respondents in this study.

\section{Results}

The findings in this study represent the integration of a rural Mexican immigrant community into mainstream local religious culture. Religion, ethnic 
traditions, language, and work all proved to be common factors which united the rural community and allowed for the perpetuation of Mexican norms and traditions despite the vast distance between the respondents, other Mexican immigrant communities in the Midwest, and their homeland. Participation in Matachines dance traditions as both a dancer and observer functioned to transmit traditional Mexican cultural and religious ideologies of U.S. born children of Mexican migrants, reinforce traditional customs and norms of behavior, and in many ways served to maintain a sense of normalcy for Mexican migrants so far from home. All of these positive functions represent the benefit of participating in Matachines traditions in order to facilitate cohesion within the new immigrant community and to produce religious and spiritual fulfillment.

\section{Religious Identities}

Religion was of primary importance to the Mexican immigrants in their new congregation. An overwhelming consensus of respondents cited their religious values as a pillar of Mexican identity. Indeed, the dancers in the Matachines dance group participated in the dance group because they felt it is the best way they could possibly venerate La Virgen de Guadalupe and "be Mexican" and thus "good ethnics" (Waters 1990; Macias 2004). The respondents were proud of their heritage and historical connections to La Virgen de Guadalupe and repeatedly cited Her as the basis of their faith and values. While the dance performances were often within the confines of a Catholic Church, the connection to indigenous pagan religions is ever present. This once again reflects the synchronization of religious beliefs and cultural practices. In this case, La Virgen de Guadalupe served not only as a source of inspiration for the dancers but also as a symbol of ethnic pride. Many Mexican-Americans attempt to learn about their ancestral past through their devotion to La Virgen de Guadalupe and practice of Catholicism (Macias 2004). However, this surge of public displays of religiosity is rather recent to the rural parish in this study. According to a brief history of the St. Stephen's Catholic Church's Hispanic Ministry's development provided on the church website, starting in September of 2000, various parishioners began to make a conscious effort to include the growing Latino/a population, particularly Mexican immigrants, who have been arriving in the Midwest for various reasons mentioned in interviews, including: work, family, and security. The church website provides a detailed description of the process by which they assessed the need to integrate Latino/as into the parish. They began going door-to-door where they knew there were Hispanic families. They created a survey with some questions including: Are you Catholic? Would you like to have a Mass in Spanish? There is a Catholic Church here, St. Stephen's, and the priest is willing to let us have Mass in Spanish. How many members are in your family? This group obtained the addresses and phone numbers of individuals in the area wanting a Mass in Spanish. In about two weeks they had compiled a list of roughly one hundred families from the surrounding area interested in having Mass in Spanish.

The common theme that existed between all interviewees is the sense of religious identity that they feel La Virgen de Guadalupe fulfills in them. One respondent, Rogelio, commented, “La Virgen helps me.
She watches to make sure I am okay." This respondent receives a sense of security from his devotion. Throughout the interview he commonly would go into long stories to help emphasize his points. It seems as if every time he is in need of something, La Virgen de Guadalupe provides it for him. "I don't know if you know, but La Virgen is the patron saint of Mexico. She is the protector of all Latinos, especially Mexicans. She came to us and showed us the way." This respondent identifies completely with La Virgen. When asked for the source of this deep devotion and faith, he responded, "La Virgen gave me everything I have, so I pray the rosary every day to thank her. You have to give thanks." This attitude transcended almost all interviews. Respondent after respondent gave thanks to La Virgen and attributed their blessings to her help. Statements such as, La Virgen me trajo a Jesucristo ["La Virgen brought me to Jesus"] and La Virgen es la madre de todos los Latinolas ["La Virgen is the mother of all Latino/as"] were very common among respondents in the dance group.

Having been immersed in this rural, predominantly White Catholic church for two years, I was able to investigate the actual daily and weekly practice of Catholicism among parishioners. This yielded interesting differences between Mexicans and Whites. When asked if they have noticed any differences in the Catholic traditions practiced between Mexican and Whites, one respondent, Luis, stated,

When they come, they sit, they don't do anything. When it is time to cross themselves, they move their hand, but they don't have the same emotion we do. We are there to celebrate and give thanks. Sometimes I don't know why they come.
I must note that none of the respondents felt any hostility towards parishioners who did this. All felt that the emotion was lacking, but at no point was the faith of any parishioner in question. This proclivity to connect emotion with religiosity resembles that of the African-American community Du Bois (1899) observed. For the respondents in the study, the Matachines dance group is a vital outlet for this emotional form of practicing religion.

This is not to say that there is a "right" way and a "wrong" way to be Catholic in rural America. Ethnic identities drive religious traditions and even create different practices. There is not one single Catholic identity. History, culture, and the environment in which people find themselves all shape their religious character and identity. In this study, devotion to La Virgen de Guadalupe was very much a Mexican phenomenon. A devout following of Guadalupanos held their patron in their consciousness in all parts of their lives. Mexican immigrants maintain strong ties with their heritage through devotion to La Virgen despite nationality and geographic location. This practice links them to their past, their families, and their communities. Durkheim (1915) suggested that religion functioned as a marker of social identity which provides individuals with membership to a social group. Regular attendance at Catholic masses and participation in Matachines rituals and public veneration to La Virgen de Guadalupe are almost a prerequisite to gaining access to the Mexican immigrant community. This is to say that in order to be "marked" as a member of the community, individuals must present themselves in accordance with these accepted roles and religiosity. 


\section{Matachines Traditions and Ethnic Identities}

The participants in this study are modern day examples of the synchronization of religions that began many years ago upon the arrival of the Spaniards in what is now modern day Mexico and began imposing Catholicism. Through traditional dance, the Mexican immigrants are simultaneously expressing their uniquely Mexican past and present religious devotion. This quest for affirmation of culture and identity may perhaps serve as a reason for the success of the Matachines dance group. In the seven years since the development of the Matachines dance group, it has gained over thirty members. This would suggest that the Matachines tradition is very much an integral part of the Mexican identity in this rural area.

A new member to the dance group, Julio, was motivated to join the dance group because of his desire for membership in the Mexican immigrant community. He stated, "I see everybody, all the people I know talking about Matachines for the event in December and I think I want to be part of that. My wife say to join, too, so I join last year." The cohesiveness of the group was evident in small everyday acts that the group members would help each other with. For example, one interview subject was late to our scheduled interview time because he volunteered to take his friend, a member of the dance group, to the store to get groceries. This act is even more important to the group because the person being helped was not a legal U.S. citizen and did not speak English. When asked about what motivated him to help, the dancer, Miguel, just said, A veces todos necesitamos ayuda [“We all need help some- times"]. This attitude embodied the overall attitude of the Matachines dance group. The significance of the dance group crossed the spiritual lines which it was based on and had a strong impact on the individual lives of the dancers.

The maintenance of Mexican ethnicity was a common theme that emerged from interviews with the Matachines dance group. Many respondents, in particular women, commented that, for one reason or another, they did not want to immigrate to the Midwest at first, but are now comfortable with their surroundings. This may, in part, be due to the community formed through the Catholic Church, and even more specifically, the Matachines dance group. In this sense, membership in the group affords multiple rewards beyond religious fulfillment. A common sense of unity was very evident in observations of conversations between dance members, respondents' willingness to introduce me to their friends for interview purposes, and, most clearly, their interview responses. At one point in the search for interviewees, I was lead around by Magdalena and introduced to all her friends. Despite my insistence that I was only interested in talking to Mexican dance group members, she had me talk with all of her friends, most of whom did not meet the interview criteria.

All of the group members relied on each other for support, guidance, and friendship. The community of Mexican-Americans in the dance group was extremely reliant on the support given to each other. It was often the case that the dancers did not know the Matachines dances they were performing before joining the dance group. This theme resurfaced commonly with several respondents admitting that they had never seen or danced the Matachines dances before joining the group at church. Franco, who had been dancing at the church for seven years, said, "When I move here, I did not know there is Catholic church. After six years we find out and then we come. I see one time the Matachines dancing and I go talk to the man in charge and he say I can join. I learn how to dance at the practices." Franco, who had been born and raised in Chihuahua, Mexico, was unaware of this tradition. Now, in the rural American Midwest, dancing in the Matachines dance group allows Franco, and his fellow dancers, to maintain a connection to their culture and ethnic identity. Although Franco was unable to explain the exact meanings or origins of the dances, he felt they connected him to who he was and thus gained a strong sense of pride from his involvement and is now, six years later, the head dancer, El Monarca.

Carmen reinforces this idea with one of her responses. When asked how life at home is different for her now relative to how it was in the past, she responded,

Yo como de todo. Pues, como de alla y aca. Tengo mis tradiciones pero he vivido muchos anos aquí. Me gusta aqui y de lo mio. Mis costumbres los traigo. Aqui en los Estados Unidos hay de todo. Pero, lo que vivi, ya lo vivi. Me retiro mucho de esas cosas.

[I eat all types of food, from here and from there (home in Mexico). I have my traditions, but I've lived here for many years. I like what's here and what's mine (Mexican traditions). I bring my customs with me. Here, in the United States, there is everything. But, what I've lived, I've lived. I don't do those things as much anymore]
In this response, Carmen has demonstrated the complexity of life for many rural immigrants. She mentions her pride in her heritage and also her desire to be part of the American way of life. Her life has become a synchronization of two cultures much like the religious synchronization which occurred so many years ago. Carmen, like the other Matachines dancers in this study, exhibits a slow integration into Midwestern American culture and practices.

Observations of group activities and interviews also confirmed the role that language plays in producing solidarity. One dancer, Felipe, reflected on his personal preference of Spanish by stating:

If I am with someone who don't speak Spanish, but when I am with Mexican people, my friends, we all speak Spanish. It feels weird if I try to talk to my friends in English. Sometimes someone say, an American guy will be with us and he will hear us speaking Spanish and he knows we speak English and he will say, why don't you speak English? You both speak English. Well, yes, but we feel weird.

Language, in this case, Spanish, proves to be a symbolic form of social capital which binds immigrants in the local community and preserves a sense of normalcy.

\section{The Mexican-American Family System}

The themes and data that emerged through the interviews and observations have close ties with previous work in the study of Mexican-American identity and the role of family in the development of identity (Telles and Ortis 2009; Jimenez 2010). 
Family-first ideologies were perhaps the most common trait shared amongst the Mexican immigrants in this religious community. Interestingly, while all of the dancers interviewed expressed a profound belief in the importance of their families in their lives, it quickly became clear that the respondents had a very traditional ideology of family structure and dynamics. Women are expected to submit to their husbands and sacrifice their own desires for the betterment of the family much like gendered historical accounts of La Virgen de Guadalupe. All of the women interviewed agreed that family is to come first before anything else. One mother, Jimena, stated in an interview, Mi familia es mi vida. No puedo ser sin mis hijos o esposo. Como trabajo en casa, hago todo para ayudar a mi familia [“My family is my life. I cannot live without my children or my husband. Since I work at home, I do everything possible to help my family"]. A similar response was given by Jaime when asked about the importance of family in his life. Jaime responded, No tengo muchas cosas en mi vida, pero si tengo mis hijos. Trabajo y trabajo, y mi esposa también para que tengan mejor vida que nosotros cuando éramos chiquitos ["I don't have a lot of things in my life, but I do have my children. I work and work, and my wife does, too, so that they (kids) can have a better life than us when we were little"]. The search for jobs and a better life for children was perhaps the most common link that all respondents shared most consistently. Many of the members of the community in this study have similar stories as to their reason to migrating to the Midwest. The availability of jobs in gardening and construction was the overwhelming response for most dancers when asked about their reasons for settling in the rural Midwest. A consensus of work- ing towards a better life and brighter future for the dancers' children was clearly evident among both the men and the women of the dance group. One dancer, Carmen, when asked what brought her to the area, described her journey to rural Midwest as the following,

Bueno, dos cosas, trabajo y familia. Mi familia empezó a mudar a los Estados Unidos cuando yo era joven. Primero una tia y un tio. Nos invitataron pero no queriamos. Cuando me mude, No me gusto. Prefiero mi pais. Pero enontre a mi esposo. Toda mi familia esta aqui ahora. [Well, two things, work and family. My family started to move to the United States when I was very young. First an aunt, then an uncle. They invited us, but we didn't want to go. When I did move, I didn't like it. But, I found my husband and all my family is here now]

This response supports the literature which suggests migration flow is heavily influenced by familial influences. Sarah Harbison (1981:226) writes that the family "is the structural and functional context within which motivations and values are shaped, human capital is accrued, information is received and interpreted, and decisions are put into operation." In her case, Carmen felt the move to the region would benefit her because of the support she would receive from having family so nearby. Support came in many forms within the immigrant, and more specifically, the Matachines community.

Durkheim (1915) suggested religious practice was a means of socialization. This is to say religion unites people through the indoctrination of norms, values, and expectations. Matachines and Guadalupanos affirm their beliefs in the central values of
Mexican ethnicity and Catholicism through commitment to these specific religious practices. Religion has generated (and continues to maintain) the collective conscience of the rural Mexican immigrants in this rural setting. For example, it was found that the children of the Mexican immigrants who have not lived in Mexico and have no knowledge of its culture are forced by their parents to participate in the Matachines dance group. Thus, the role of the dance group goes beyond a religious practice. Parents look to these rituals and symbols as a means of socializing their children into their culture in order to maintain ethnic ties to their ancestral homeland. Durkheim (1915) argued that religion formed a moral community in society where members were socialized into accepting appropriate patterns of behavior. Most Matachines dancers tie their religious and ethnic identities and thus their values and beliefs to the Catholic Church at the institutional level and then to their dance group at the sub-institutional level. Stephen Cornell and Douglas Hartmann (2007) offer a possible explanation for this phenomenon of the role of Matachines traditions as a means of socializing individuals of the community. They write,

This observation is important for understanding identity construction. It underlines the point that the making of a collective identity is not, generally speaking, a process through which unconnected, isolated individuals come together and gain a consciousness of themselves as constituting a group. [Cornell and Hartmann 2007:212]

This is to say that these religious symbols and rituals represent a pillar of Mexican ethnicity and are used in the communal maintenance and construction of identity. In the case of this rural context, the Matachines dance group is the vehicle which enables the Mexican immigrant community to maintain an ethnic and religious identity and to integrate their religious values and perspectives into the local church.

The integration process into mainstream American culture is becoming increasingly complicated and difficult as the children of respondents are beginning to be exposed to more diversity outside of this tight-knit community while attending elementary, middle, and high school and beginning to intermingle with people of various races and ethnicities, something their parents do not frequently do. When asked about raising children and its difficulties in such an isolated region of the Midwest, Paulina described the uphill battle she faces. She stated,

Pues, es dificil, no. Quiero que mis hijos sepan de nuestra cultura y de mi familia pero no estan interesados. Salgan con sus amigos y no se que hacen. Los domingos cuando vamos a la misa y vemos a nuestro pueblo es cuando me siento bien y que mis hijos no van a perder sus culturas.

[Well, it's hard, you know? I want my children to know about our culture and my family, but they're not interested. They go out with their friends to do I don't know what. On Sunday's when we go to mass and see our people is when I feel good and that my children are not going to lose their culture]

This same sentiment echoed in other interviews with mothers of the group. Lola and Gabriela were two very close friends with the same predicament. They felt their children's lack of interest in their culture was a sign of the American influence on them. 
Lola described the situation with these words, No dudo que es major criar mis hijos aqui [in the United States] pero a veces no entiendo sus acciones. Es como no son mis hijos ["I don't doubt that it is better to raise my children here (in the United States)], but sometimes I just don't understand what they do. It's like they aren't even my children"]. It was her friend Gabriela who suggested to her that she get her kids involved in the Hispanic ministry at the church. It was through this involvement that her children came to be involved in the Matachines dance group and thus were exposed to the culture of their parents and family. Gabriela spoke of this suggestion with pride. She exclaimed, Sus hijos no van a perder su cultura [laughs] porque yo no voy a permitir eso! ["Her children aren't going to lose their culture (laughs) because I won't let it happen!"]. In this case, Lola was receiving support from another woman in her community to ensure that she passes down the correct values and culture to her children. Community and its influences proved to be an important theme in this research. The maintenance of culture was very much reliant on others and the knowledge and experience they were able to pass on and learn from each other.

\section{Conclusions and Discussion}

In this study, Mexican immigrants living in the rural Midwest were relatively isolated from any large Mexican population. Faced with this reality, members of the community turned to a local Catholic Church and a Matachines dance group in particular, as a strategy for maintaining their culture and values uniquely associated with their Mexican ethnicity and integrating their religious values into the local organizational church. By connecting with a group of peers, the dancers are able to maintain a form of normalcy in their lives and are better able to balance the various external forces to assimilate to mainstream Midwestern culture and practices. As more and more immigrants continue to enter this rural community, the Matachines dance group is fully expected to continue to grow. As it grows, the transmission of values pertaining to ethnic expressions of the family, the institutional church, and religious symbols will undoubtedly maintain their strong presence.

The Matachines dance group in this study has struggled to maintain a concrete Mexican identity. However, research participants displayed their ethnic pride, as well as their hope in the American dream. The interplay of external assimilatory social forces on everyday life was a large obstacle in daily lives. Involvement in a moderate-sized Matachines dance group had a profound impact on the Mexican-American community members' ability to construct and maintain their identity in such an isolated region of the country. The Roman Catholic Church fulfilled two major needs for the dancers. First, it served as a means for networking among other Mexican-Americans in the area. Second, it also allowed for the continuation of traditional practice of faith for the Mexican-Americans who were able to attend mass in Spanish and participate in the Matachines dance group. The dance group allowed the Mexican-American community to come together around one very important aspect of Mexican-American culture. For most respondents, the origin and meanings of the dances were not clear. Most of the dancers learned about and were able to get in touch with their own culture and past as they began to dance and follow the Matachines traditions. Invented tradition or not, the powerful impact of the dance on the dancers' lives was unmistakable. The parents of the dance group used the practices almost like a history class where their children could learn about their ancestry and continue to transmit their culture to future generations. The dancers were very proud of their Matachines traditions and wanted to show everyone who they were. Exclaiming this point with pride, El Monarca of the dance group stated, "It's in our blood!" By participating in this dance group, the Matachines dancers, their children, and the surrounding Mexican-American community are making sure their culture, values, and ideologies stay "in their blood" and continue to be passed on to future generations.

The Matachines dance group became of central importance to Mexicans and Mexican-Americans because of the rural area in which it was located. The Mexican-American community came together around the religious and cultural traditions they shared. Future research could explore the role of gender in this Mexican-American community as it relates to the Matachines dance group. Do the danc-

\section{References}

Arbelaez, Maria. 2002. “Good Friday in Omaha, Nebraska: A Mexican Celebration." Great Plains Research 12(1):13-26.

Arreola, Daniel, (ed.). 2004. Hispanic Spaces, Latino Places: A Geography of Regional and Cultural Diversity. Austin: University of Texas Press. ers take on this gender neutral stance to demonstrate their assimilation to mainstream American culture? Or, could it be as simple that the dancers are instructed by the leaders of the church to ensure equality? Future research could also explore the prevalence of Matachines traditions outside the Roman Catholic Church to examine the power dynamics between ethnic and religious identities.

Previous research (Waters 1990; Jimenez 2010) suggests that without a continuous flow of immigrants to replenish the identities of previous immigrants, the immigrant communities in question are more likely to be on a trajectory towards fully assimilating into mainstream American society. In my research, a continuous flow of Mexican immigrants has "replenished" the ethnicities of the locals who have been there for a period of time ranging from a couple to several years. The new immigrants motivated the continuity of cultural practices and traditions, such as public devotion to La Virgen de Guadalupe and Matachines dances. Future research may revisit the rural community in this study to examine the flow (legal and illegal) of immigrants to the rural area and its impact on the ethnic resilience of the immigrant community. 
Cornell, Stephen and Douglas Hartmann. 2007. Ethnicity and Race: Making Identities in a Changing World. Thousand Oaks, CA: Pine Forge Press.

Delgado, Angel A. 2007. “Danza de Matachines: Estructura Y Función Entre Los Raramuri De La Sierra Tarahumara." Revista de Antropologia Iberoamericana 3:95-112.

Du Bois, William Edward Burghardt. 1899. The Philadelphia Negro. Philadelphia: University of Pennsylvania Press.

Durand, Jorge, Douglas S. Massey, and Fernando Charvet. 2000. "The Changing Geography of Mexican Immigration to the United States: 1910-1996." Social Science Quarterly 81:1-15.

Durkheim, Emile. 1915. The Elementary Forms of Religious Life. London: Allen and Unwin

Fuhlhage, Michael. 2007. From the Margins to the Majority: Portrayal of Hispanic Immigrants in the Garden City (Kan.) Telegram, 1980-2000. M.A. Dissertation. University of Missouri, Columbia.

Gomez, Laura. 2007. Manifest Destinies: The Making of the Mexican American Race. New York: NYU Press.

Gordis, David M. and Yoav Ben-Horin. 1991. Jewish Identity in America. Los Angeles, CA: Susan and David Wilstein Institute of Jewish Policy Studies.

Guzman, Betsy. 2001. "The Hispanic Population: Census 2000 Brief." U.S. Department of Commerce Economics and Statistics Administration: U.S. Census Bureau.

Hammond, Phillip E. and Kee Warner. 1993. "Religion and Ethnicity in Late Twentieth Century America." Annals of the American Academy of Political and Social Science 527:55-66.

Harbison, Sarah F. 1981. Family Structure and Family Strategy in Migration Decision Making. New York: Center for Cultural and Technical Interchange Between East and West.

Jimenez, Tomas. 2010. Replenished Ethnicity: Mexican Americans, Immigration, and Identity. Berkeley, CA: University of California Press.
Kandel, William and John Cromartie. 2004. "New Patterns of Hispanic Settlement in Rural America." Report 99. U.S. Department of Agriculture.

Kandel, William and Robert M. Gibbs. 2005. "Hispanic Population Growth and Labor Force Reception in New Rural Destinations of the United States." Paper presented at the Annual Meeting of the Population Association of America, March 29-April 02 Philadelphia.

Kelly, Mary E. and Tracy X. Karner. 1994. “Reclaiming and Inventing Ethnic Identity: Lithuanians and Finns at the Turn of the Twentieth Century." Journal of Ethnic Studies and Ethnic Bibliography 14:5-22.

Kurath, Gertrude P. 1949. “Mexican Moriscas: A Problem in Dance Acculturation." Journal of American Folklore 62:87-106.

Lafaye, Jacques. 1976. Quetzalcoatl and Guadalupe: The Formation of Mexican National Consciousness 1531-1813. Chicago: University of Chicago Press.

Lichter, Daniel T. et al. 2007. "National Estimates of Racial Segregation in Rural and Small-Town America." Demography $44(3): 563-581$

Macias, Thomas. 2004. "Imaginandose Mexicano: The Symboli Context of Mexican American Ethnicity Beyond the Second Generation." Qualitative Sociology 27(3):199-315.

Massey, Douglas S. and Magaly Sanchez R. 2006. "Latino and American Identities as Perceived by Immigrants." Qualitative Sociology 30:81-107.

Menjívar, Cecilia. 1999. “Religious Institutions and Transnationalism: A Case Study of Catholic and Evangelical Salvadoran Immigrants." International Journal of Politics, Culture, and Society 12(4):589-612.

Rodriguez, Sofia. 2007. The Matachines Dance: A Ritual Dance of the Indian Pueblos and Mexicano/Hispano Communities. Santa Fe: Sunstone Press.

Saenz, Rogelio, Cynthia M. Cready, and Maria Cristina Morales, (eds.). 2007. “Adios Aztlan: Mexican American Out-Migration From the Southwest." Sociology of Spatial Inequality. Albany, NY State University New York Pres
Stout, Harry. 1975. "Ethnicity: The Vital Center of Religion in America." Ethnicity 2:204-224.

Tafoya, Sonya M. 2004-2005. "Shades of Belonging. Latinos and Racial Identity." Harvard Journal of Hispanic Policy 17:55-78.

Telles, Edward and Vilma Ortiz. 2009. Generations of Exclusion: Mexican Americans, Assimilation, and Race. New York: Russell Sage Foundation.

Waters, Mary. 1990. Ethnic Options: Choosing Identities in America. Berkeley, CA: University of California Press.
Waters, Mary C. and Tomas Jimenez. 2005. "Assessing Immigrant Assimilation: New Empirical and Theoretical Challenges." American Sociological Review 31:105-125.

Yang, Fenggang and Helen Rose Ebaugh. 2001. "Transformations in New Immigrant Religions and Their Global Implications." American Sociological Review 66:269-288.

Zuniga, Victor and Ruben Hernandez-Leon. 2005. New Destinations of Mexican Immigration in the United States: Community Formation, Local Responses, and Intergroup Relations. New York: Russell Sage Foundation. 